\title{
Relationship between the Lipid Accumulation Product Index and Alanine Aminotransferase in Korean Adult Men
}

Kyung-A Shin

Department of Clinical Laboratory Science, Shinsung University, Dangin, Korea

\section{한국 성인남성에서 Lipid Accumulation Product 지수와 Alanine Aminotransferase와의 관련성}

\author{
신경아 \\ 신성대학교 임상병리과
}

\begin{abstract}
The LAP (lipid accumulation product) index is an indicator of excessive fat accumulation in combination with the fasting triglyceride concentration and waist circumference. This study examined the relationship between the LAP index and ALT (alanine aminotransferase) level and the effect of the LAP index on the ALT level. Cross-sectional studies were conducted on healthy adult males without a history of liver disease. From January 2015 to June 2017, 13,854 adults between 20 and 70 years of age, who underwent health screening at a general hospital in Gyeonggi-do, were enrolled in this study. The LAP index was calculated as [waist circumference $(\mathrm{cm})-$ $65] \times[$ triglyceride $(\mathrm{mmol} / \mathrm{L})]$ for males. Serum ALT abnormalities were set at $40 \mathrm{IU} / \mathrm{L}$ or more in males. All subjects underwent measurements of the anthropometric indicators and physiological examinations. A significant increase in ALT with increasing LAP quintiles was observed ( $p$ $<0.001)$. The LAP index correlated with ALT $(r=0.238, p<0.001)$. Insulin $(r=0.449, p<0.001)$ and $\mathrm{HDL}-$ cholesterol $(r=-0.369, p<0.001)$ were strongly correlated with LAP. In addition, the LAP index is a factor affecting the ALT level $(p<0.001)$. As the LAP index increased, the risk of an elevated ALT was higher $(p<0.001)$. In conclusion, the LAP index was a predictor of an ALT elevation in Korean men.
\end{abstract}

Key words: Lipid accumulation product, Alanine aminotransferase, Non-alcoholic fatty liver disease

This is an Open Access article distributed under the terms of the Creative Commons Attribution Non-Commercial License (http://creativecommons.org/licenses/by-nc/4.0) which permits unrestricted non-commercial use, distribution, and reproduction in any medium, provided the original work is properly cited.

Copyright (c) 2017 The Korean Society for Clinical Laboratory Science. All rights reserved.
Corresponding author: Kyung-A Shin Department of Clinical Laboratory Science, Shinsung University, 1 Daehak-ro, Jeongmi-myeon, Dangjin 31801, Korea Tel: 82-41-350-1408

Fax: 82-41-350-1355

E-mail: mobitz2@hanmail.net

Received: October 16, 2017

Revised: November 3, 2017

Accepted: November 5, 2017

\section{서 론}

LAP 지수(lipid accumulation product index)는 공복시 중 성지방 농도와 허리둘레에 근거하여 과도한 중심성 지방 (central lipid)의 축적을 평가하는 지표이다[1]. LAP 지수는 2005년 Kahn에 의해 처음 제시되었으며, 체질량지수(body mass index, BMI)보다 심혈관 질환, 대사증후군 및 제 2형 당뇨 병의 위험을 더 잘 예측하는 지표로 보고된다[1,2]. 복부지방은
피하지방과 내장지방으로 구성되며, 내장지방은 피하지방보다 심혈관계 대사질환 위험(cardiometabolic risk) 및 심혈관 질 환과 더 밀접하게 연관되어 있다[3]. 또한 내장지방은 피하지방 보다 지방분해 속도는 빠르지만, interleukin-6 및 플라스미노 겐 활성화인자 억제제-1 (plasminogen activator inhibitor-1, $\mathrm{PAI}-1$ )과 같은 아디포사이토카인(adipocytokines)의 생성을 증가시킨다[4]. 그러나 BMI와 허리둘레 같은 전통적인 인체측 정학적 변인은 내장지방과 피하지방을 분별하지 못하므로 내장 
지방을 평가하기 위한 인체계측 지표의 필요성이 제시되었다 [5-7]. LAP 지수에 포함되는 중성지방은 내장지방을 평가하는 유용한 지표로 제시되며[8], 허리둘레와 함께 중성지방을 측정 함으로써 대사증후군, 당뇨병 및 관상동맥 질환의 위험 증가를 예측할 수 있는 인자로 보고된다[9-12]. 더욱이 LAP 지수는 일 반인과 더불어 심혈관 질환의 위험이 높은 환자에게서 공복혈 당, HDL-콜레스테롤(high density lipoprotein-cholesterol) 및 수축기 혈압과 상관관계가 있음이 보고되었다[1,2,13].

한편, 알라닌 아미노전이효소(alanine aminotransferase, ALT)는 간세포 손상을 평가하는 일반적이고 유용한 지표로서, 다른 간 효소에 비해 간 내 지방축적을 잘 반영한다[14,15]. 비 알콜성 지방간질환(non-alcoholic fatty liver disease, NAFLD) 은가벼운 지방간에서 비알코올성 지방간염, 섬유증, 간경화, 간 기능 장애까지 포함하는 광범위한 질병으로 ALT 상승과 밀접한 관련성을 보여 ALT는 비알콜성 지방간질환의 대체지표로 이용 된다[16,17]. 고중성지방혈증은 근육 및 간세포 내에 중성지방 의 축적을 동반하며, 이소성 지방 침착과 비알콜성 지방간질환 의 발현에 기여하는 것으로 알려져 있다[18,19]. 또한 과도한 내 장지방에 의한 복부비만은 비알콜성 지방간의 진행에 중요한 역할을 한다[20,21]. 그러므로 중성지방과 허리둘레의 조합으 로 구성된 LAP 지수는 간 지방증(steatosis)의 중증도에 비례하 여 증가하며, 비알콜성 지방간과 관련이 있는 것으로 추정된다 [22]. 그 예로 Ji 등[22]은 LAP가 ALT와 관련이 있으며, 심혈관 질환 및 대사성 질환뿐만 아니라 혈청 ALT 및 간 손상과도 밀접 한 관련이 있는 지표라고 보고하였다. 그러나 신체구성은 민족 적 특성에 따라 크게 다른데 선행연구들은 주로 미국 및 유럽인 을 대상으로 이루어졌으며, LAP 지수를 계산하는 공식이 서양 인을 대상으로 한 연구로부터 파생되어 국내에 적용 가능한지 는 아직까지 불분명하다[1,5]. 동양인을 대상으로 시행된 연구 결과에 따르면 LAP 지수는 ALT와 독립적인 상관관계가 있지 만, 남성에서만 독립적인 상관관계가 있음을 입증하였다[22]. Dai 등[23]은 LAP 지수가 비알콜성 지방간과 관련이 있으며, 비 알콜성 지방간에 대한 진단 정확도가 특히 젊은 연령층에서 높 다고 보고하였다. 이는 서양인을 대상으로 한 연구결과와 유사 한 결과이기는 하나 서양인과 비교해 동양인은 동일한 BMI에도 불구하고 상대적으로 체지방 및 내장지방이 많으며, BMI와 허 리둘레가 낮더라도 심혈관 질환의 위험이 높은 특징을 보이고 있어 LAP 지수에 대해 한국인을 대상으로 한 평가가 필요하다 [24]. 또한 LAP 지수를 평가한 연구들은 간 질환 및 심혈관 질환 의 위험군, 다낭성 난소증후군 환자 및 제 2 형 당뇨환자를 대상 으로 그 관련성을 평가하고 있으며[13,25-27], 국내의 건강한
성인에서도 LAP지수와 ALT간에 관련성을 이끌어 낼 수 있는지 확인이 요구된다.

이에 본 연구에서는 LAP 지수와 ALT간의 관련성과 LAP 지수 가 ALT에 미치는 영향을 확인하여 ALT 상승을 예측하는 지표로 $\mathrm{LAP}$ 지수가 유용한지에 대해 알아보고자 간질환의 병력이 없는 한국의 건강한 성인남성을 대상으로 횡단면 연구(cross-sectional study)를 실시하였다.

\section{대상 및 방법}

\section{1. 연구 대상}

이 연구는 경기지역 일개 종합병원에서 2015년 1월부터 2017년 6월까지 건강검진을 시행한 20세 이상 70세 이하의 성 인남성을 연구 대상자로 하였다. 14,265 명의 전체 대상자 중에 서 해당하는 자료에 결측치(missing data)가 있는 279건을 제 외하였다. 또한 간질환의 병력이 있는 경우, 간암, 간경화증, $\mathrm{B}$ 형 간염보균자, 심한 이상지질혈증으로 현재 지질 강하제를 복 용 중인 피험자 132 명은 제외하였으며, 최종 연구에 포함된 대 상자는 13,854 명이었다. 질환과 관련된 병력 및 지질 강하제 복 용에 대한 자료는 자기기입식 설문지를 통해 얻었으며, 이 연구 는 경기지역 종합병원 기관생명윤리심의위원회(Institutional Review Board, IRB) 심의를 받아 승인 후 연구를 수행하였다 (IRB No: D-1207-002-0110).

\section{2. 연구방법}

\section{1) 신체계측 및 혈압측정}

신장 및 체중은 체성분 분석 장비 Inbody 720 (Biospace Co., Seoul, Korea)으로 측정하였으며, BMI는 측정된 신장과 체중을 이용하여 체중 $(\mathrm{kg}) /$ 신장 $\left(\mathrm{m}^{2}\right)$ 의 공식으로 계산하였다. 허리둘레는 $\mathrm{WHO}$ 에서 권고하는 방법에 따라숨을 내쉰 상태로 늑골 하단부분(lower border of rib cage)과 장골능 상부(top of iliac crest)의 중간 부위를 측정하였으며, 엉덩이 둘레는 측 면에서 확인하였을 때 엉덩이의 가장 높은 부위를 줄자로 측정 하였다. 수축기 혈압과 이완기 혈압은 mercury sphygmomanometer (Baumanometer, WA, NY)로 안정시 왼팔에서 2회 측정하여 평균값을 자료로 이용하였다.

\section{2) 진단기준 및 혈액분석}

LAP 지수는 Kahn이 제안한 방법에 따라 남성의 경우 [허리 둘레 $(\mathrm{cm})-65] \times[$ 중성지방 $(\mathrm{mmol} / \mathrm{L})]$ 로 산출하였다[1]. 또한 혈청 ALT 농도의 이상치는 Clark 등[14]이 제시한 남성 $40 \mathrm{IU} / \mathrm{L}$ 
이상인 경우를 이상치의 기준으로 설정하였다. 혈액검사는 8시 간 이상 공복상태로 전완정맥(antecubital vein)에서 채혈 후 분석하였다. ALT, 총콜레스테롤, 중성지방, LDL-콜레스테롤 (low density lipoprotein-cholesterol), HDL-콜레스테롤, 공 복혈당, 요산, 고감도 C-반응단백(high sensitivity C-reactive protein, hs-CRP)은 TBA-200FR NEO (Toshiba, Tokyo, Japan) 자동생화학분석기로 측정하였다. ALT의 활성도는 JSCC UV법의 원리로 측정하였으며, 고감도 C-반응단백은 면 역비탁법(turbidimetric immunoassay, TIA)의 원리로 측정하 였다. 당화혈색소(hemoglobin A1c, HbA1c)의 측정은 전혈 검 체로 고성능액체크로마토그래피(high performance liquid chromatography, HPLC)분석법으로 Variant II (Bio Rad, CA, USA) 장비를 이용하여 측정하였다. 인슐린은 전기화학발광면 역분석법(electrochemiluminescence immunoassay, ECLIA) 으로 Roche Modular Analytics E170 (Roche, Mannheim, Germany)을 이용하여 검사하였다. 인슐린 저항성을 간접적으 로 평가하는 인슐린 저항성 지수(homeostasis model assessment-insulin resistance, HOMA-IR)는 공복혈당과 공복 인 슐린 농도를 이용하여 [공복 인슐린 농도 $(\mu \mathrm{IU} / \mathrm{mL}) \times$ 공복혈당 $(\mathrm{mg} / \mathrm{dL}) / 405]$ 공식으로 계산하였다[28].

\section{3. 통계분석}

이 연구는 IBM SPSS Statistics 24.0 (IBM, NY, USA) 통계분 석 프로그램을 이용하여 연구자료를 통계 처리하였다. 모든 데 이터는 평균 \pm 표준편차로 표시하였다. LAP 사분위수에 따른 인체측정학적 및 생화학적 변인의 차이를 비교하기 위해 일원 분산분석(one way analysis of variance, ANOVA)으로 확인하 였으며, LAP 사분위수의 집단간 유의한 차이가 있는 경우 bonferroni 검증방법으로 사후검증(post-hoc test)을 하였다. $\mathrm{LAP}$ 지수와 ALT 및 심혈관계 대사질환 위험인자간의 상관성 정 도를 알아보고자 상관관계분석(correlation analysis)을 시행 하였다. 또한 LAP 지수가 ALT에 미치는 영향을 예측하기 위하 여 다중회귀분석(multiple regression analysis)을 실시하였으 며, LAP 사분위수에 따른 ALT 이상치의 발생가능성을 예측하 기 위해 이분형로지스틱 회귀분석(binominal logistic regresSion)을 적용하였다. 허리둘레와 중성지방 농도는 연령 증가와 함께 증가하는 경향을 보이므로 이 연구에서는 연령을 통제한 후 통계분석을 실시하였다[29]. 이 연구의 통계분석에 따른 유 의수준은 $p<0.05$ 로 설정하였다.

\section{결 과}

\section{LAP 사분위수에 따른 대상자의 인체측정학적 및 생화학적 변인의 차이}

이 연구 대상자를 LAP 사분위수에 따라 네 집단으로 분류하 여 집단간 인체측정학적 및 생화학적 변인의 차이를 확인한 결 과 연령은 1 사분위수보다 2 사분위수, 3 사분위수, 4 사분위수가 높았으며, 3 사분위수와 4 사분위수는 1 사분위수와 2 사분위수 보다 높았다 $(p<0.001)$. 신장은 4 사분위수가 1 사분위수, 2 사 분위수, 3 사분위수보다 크게 나타났다 $(p=0.001)$. 체중, BMI, 허리둘레, 엉덩이 둘레, 수축기와 이완기 혈압은 1 사분위수보 다 2 사분위수, 3 사분위수, 4 사분위수가 높았으며, 3 사분위수는 2 사분위수보다 높았고 4 사분위수는 3 사분위수보다 높게 나타 났다(각각 $p<0.001$ ). 생화학적 변인인 총콜레스테롤, $\mathrm{LDL}-$ 콜 레스테롤, 중성지방, 공복혈당, $\mathrm{HbA1c}$, 인슐린, HOMA-IR, 요 산은 1 사분위수보다 2 사분위수, 3 사분위수, 4 사분위수가 높았 으며, 3 사분위수는 2 사분위수보다 높았고 4 사분위수는 3 사분 위수보다 높게 나타났다(각각 $p<0.001$ ). 그러나 HDL-콜레스 테롤은 1 사분위수보다 2 사분위수, 3 사분위수, 4 사분위수가 낮 았으며, 3 사분위수는 2 사분위수보다 낮고 4 사분위수는 3 사분 위수보다 낮았다 $(p<0.001) . \mathrm{hs}-\mathrm{CRP}$ 는 4 사분위수가 1 사분위 수와 2 사분위수보다 낮게 나타났다 $(p<0.001)$ (Table 1). 또한 $\mathrm{LAP}$ 분위수가 증가할수록 ALT는 통계적으로 유의한 증가를 보 였다 $(p<0.001)$ (Figure 1).

\section{LAP 지수와 ALT 및 심혈관계 대사질환 위험요인간의 상관관계}

$\mathrm{LAP}$ 지수와 ALT 및 심혈관계 대사질환 위험요인간의 상관관 계 분석을 실시한 결과는 Table 2 와 같다. LAP 지수는 ALT $(r=0.238, p<0.001)$ 뿐만 아니라 허리둘레 $(r=0.623, p<0.001)$, 수축기 혈압 $(r=0.201, p<0.001)$ 과 이완기 혈압 $(r=0.201, p$ $<0.001), \mathrm{LDL}$-콜레스테롤( $r=0.120, p<0.001)$, 중성지방 $(r=0.885 p<0.001)$, 공복혈당 $(r=0.217, p<0.001), \mathrm{HbA} 1 \mathrm{c}$ $(r=0.207, p<0.001)$, 인슐린( $r=0.449, p<0.001)$, HOMA-IR $(r=0.132, p<0.001)$ 과 양의 상관관계를 보였으나, $\mathrm{HDL}-$ 콜레 스테롤 $(r=-0.369, p<0.001)$ 과는 음의 상관관계를 나타냈다. 또한 LAP 지수는 총콜레스테롤과는 상관성이 없었으며, LAP 지수의 수학적 모델 공식에 포함되는 허리둘레와 중성지방은 높은 상관성을 보였다. 
Table 1. Clinical and biochemical characteristics of subjects according to the LAP quartiles

\begin{tabular}{|c|c|c|c|c|c|}
\hline \multirow[b]{2}{*}{ Variable } & \multicolumn{4}{|c|}{ Quartiles of LAP } & \multirow[b]{2}{*}{$p$} \\
\hline & $\begin{array}{l}\text { Quartile } 1 \\
(<9.60)\end{array}$ & $\begin{array}{l}\text { Quartile 2 } \\
\text { (9.60 18.81) }\end{array}$ & $\begin{array}{c}\text { Quartile } 3 \\
(18.82 \sim 34.87)\end{array}$ & $\begin{array}{l}\text { Quartile } 4 \\
(>34.87)\end{array}$ & \\
\hline Number & 1,957 & 3,142 & 4,075 & 4,671 & \\
\hline Age (yr) & $42.24 \pm 10.34$ & $44.44 \pm 10.23^{\star}$ & $45.52 \pm 9.82^{*}+$ & $45.46 \pm 9.38^{*}{ }^{\dagger}$ & $<0.001$ \\
\hline Height $(\mathrm{cm})$ & $171.37 \pm 6.27$ & $171.31 \pm 6.21$ & $171.61 \pm 6.26$ & $172.07 \pm 6.23^{\star,},,^{\dagger}$ & 0.001 \\
\hline Weight (kg) & $63.06 \pm 7.23$ & $68.79 \pm 7.24^{*}$ & $73.08 \pm 8.10^{\star, \dagger}$ & $79.34 \pm 10.04^{*, \dagger, \neq}$ & $<0.001$ \\
\hline $\mathrm{BMI}\left(\mathrm{kg} / \mathrm{m}^{2}\right)$ & $21.59 \pm 5.59$ & $23.51 \pm 4.37^{\star}$ & $24.85 \pm 3.85^{\star, \dagger}$ & $26.85 \pm 5.30^{\star, \dagger, \neq}$ & $<0.001$ \\
\hline Waist circumference $(\mathrm{cm})$ & $73.86 \pm 4.69$ & $80.19 \pm 4.50^{\star}$ & $84.35 \pm 4.92^{*, \dagger}$ & $89.64 \pm 6.34^{*,+, \ddagger}$ & $<0.001$ \\
\hline Hip circumference $(\mathrm{cm})$ & $90.08 \pm 15.34$ & $93.65 \pm 23.70^{*}$ & $95.74 \pm 20.92^{*, \dagger}$ & $99.32 \pm 29.14^{*,+, \neq}$ & $<0.001$ \\
\hline Systolic BP (mmHg) & $107.54 \pm 11.42$ & $110.41 \pm 12.07^{\star}$ & $112.77 \pm 12.81^{*}+$ & $115.61 \pm 13.13^{\star,+, \neq}$ & $<0.001$ \\
\hline Diastolic BP (mmHg) & $69.03 \pm 8.84$ & $71.32 \pm 9.27^{\star}$ & $73.17 \pm 9.79^{*}{ }^{\dagger}$ & $75.36 \pm 10.08^{\star, \dagger, \ddagger}$ & $<0.001$ \\
\hline Total cholesterol (mg/dL) & $179.04 \pm 29.53$ & $188.39 \pm 30.68^{*}$ & $195.99 \pm 32.43^{*},+$ & $207.28 \pm 35.11^{*,+, \neq}$ & $<0.001$ \\
\hline $\mathrm{HDL}-\mathrm{C}(\mathrm{mg} / \mathrm{dL})$ & $60.49 \pm 11.89$ & $55.87 \pm 11.34^{\star}$ & $51.15 \pm 10.54^{\star, \dagger}$ & $46.24 \pm 9.47^{\star, \dagger, \ddagger}$ & $<0.001$ \\
\hline $\mathrm{LDL}-\mathrm{C}(\mathrm{mg} / \mathrm{dL})$ & $106.88 \pm 26.54$ & $117.79 \pm 28.07^{\star}$ & $125.76 \pm 29.31^{*}+$ & $129.40 \pm 32.13^{*,+, \neq}$ & $<0.001$ \\
\hline Triglyceride (mg/dL) & $65.78 \pm 26.71$ & $88.99 \pm 28.78^{\star}$ & $126.55 \pm 36.61^{*}, \dagger$ & $233.72 \pm 110.78^{\star},+, \ddagger$ & $<0.001$ \\
\hline Fasting glucose (mg/dL) & $85.05 \pm 16.02$ & $88.89 \pm 15.93^{\star}$ & $92.23 \pm 18.56^{*, \dagger}$ & $97.32 \pm 23.68^{*, \dagger, \ddagger}$ & $<0.001$ \\
\hline $\mathrm{HbA} 1 \mathrm{c}(\%)$ & $5.41 \pm 0.63$ & $5.51 \pm 0.65^{\star}$ & $5.61 \pm 0.69^{*, \dagger}$ & $5.82 \pm 0.87^{\star}, \uparrow, \ddagger$ & $<0.001$ \\
\hline Insulin ( $\mathrm{uU} / \mathrm{mL})$ & $2.70 \pm 1.90$ & $3.89 \pm 2.19^{*}$ & $5.00 \pm 2.60^{*, \dagger}$ & $7.03 \pm 3.57^{*, \dagger, \neq}$ & $<0.001$ \\
\hline HOMA-IR & $0.08 \pm 0.26$ & $0.13 \pm 0.39^{*}$ & $0.20 \pm 0.54^{*, \dagger}$ & $0.30 \pm 0.80^{*, \dagger, \ddagger}$ & $<0.001$ \\
\hline Uric acid (mg/dL) & $5.64 \pm 1.16$ & $5.78 \pm 1.17^{\star}$ & $6.07 \pm 1.19^{*}+$ & $6.43 \pm 1.35^{\star, \dagger, \ddagger}$ & $<0.001$ \\
\hline hs-CRP (mg/dL) & $0.34 \pm 1.03$ & $0.30 \pm 0.71$ & $0.27 \pm 0.57$ & $0.24 \pm 0.43^{*}+$ & $<0.001$ \\
\hline
\end{tabular}

Calculated by one way ANOVA and bonferroni test.

Values are presented as mean \pm SD.

${ }^{\star}$ Significantly different from Quartile 1 at $p<0.05,{ }^{\dagger}$ Significantly different from Quartile 2 at $p<0.05,{ }^{\dagger}$ Significantly different from Quartile 3 at $p<0.05$

Abbreviations: LAP, lipid accumulation product; BMI, body mass index; BP, blood pressure; HDL-C, high density lipoprotein cholesterol; LDL-C, low density lipoprotein cholesterol; HbA1c, hemoglobin A1c; HOMA-IR, homeostasis model assessment-insulin resistance; hs-CRP, high sensitivity C-reactive protein.

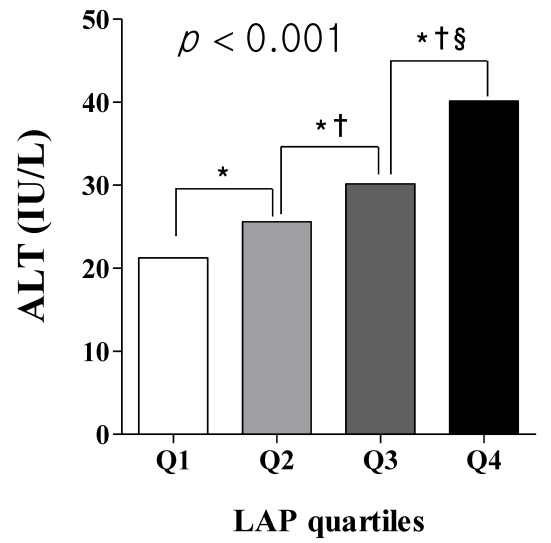

Figure 1. Mean ALT level according to the LAP quartiles. Q1; 22.22 $\pm 14.00, \quad$ Q2; 25.58 $\pm 39.40, \quad$ Q3; 30.16 $23.10, \quad$ Q4; 40.11 \pm 27.64 . Calculated by one way ANOVA and bonferroni test. *Significantly different from Q1 at $p<0.05,{ }^{\dagger}$ Significantly different from Q2 at $p<0.05,{ }^{8}$ Significantly different from Q3 at $p<0.05$. Abbreviations: LAP, lipid accumulation product; ALT, alanine aminotransferase; Q, quartile.

\section{LAP 지수가 ALT에 미치는 영향}

연령증가와 함께 허리둘레는 증가하고 지질은 과다 축적되 는 경향을 보이므로, 연령을 통제한 후 LAP 지수가 ALT에 미치
는 영향을 알아보기 위해 다중회귀분석을 실시한 결과, LAP 지 수는 ALT에 영향을 미치는 요인으로 나타났다 $(p<0.001)$ (Table 3).

\section{LAP 사분위수에 따른 ALT 이상치의 발생가능성 예측}

연령을 통제한 후 LAP 사분위수에 따른 ALT 이상치의 발생 가능성을 예측하기 위해 이분형로지스틱 회귀분석을 시행한 결 과, LAP 지수의 1 사분위수와 비교해 2 사분위수에서 ALT 이상 치 발생가능성은 2.2 배 증가하며, 3 사분위수의 ALT 이상치 발 생가능성은 4.4 배로 나타났다. 또한 LAP 지수의 4사분위수는 1 사분위수보다 ALT 이상치 발생가능성이 10.8배 증가하는 것으 로 나타나, LAP 지수가 높을수록 ALT가 상승할 위험이 높게 나 타났다(각각 $p<0.001$ ) (Table 4).

\section{고 찰}

이 연구에서는 간질환 병력이 없는 건강한 성인남성을 대상 으로 LAP 지수와 ALT간의 관련성 및 LAP 지수가 ALT에 미치는 영향을 알아보고자 하였다. 그 결과 LAP 분위수가 증가할수록 
ALT는 증가하였으며, LAP 지수는 ALT뿐만 아니라 심혈관계 대 사질환 위험요인과 상관관계를 보였다. 또한 LAP 지수는 ALT 에 영향을 미치는 요인이었으며, LAP 지수가 높을수록 ALT의 이상치 발생가능성이 높게 나타났다.

LAP 지수는 체지방 측정 값인 허리둘레와 긴 지방산 사슬 3 분자가 에스테르화된 중성지방의 조합으로 지질의 과다축적을 반영하는 지표이며, 2005년 미국 NHANES III (National. Health and Nutrition Examination Survey III)자료를 통해 Kahn이 처음 제안하였다[1]. 이 연구결과에 따르면 LAP 지수 는 심혈관계 질환, 대사증후군 및 제 2형 당뇨병의 위험을 예측 하였으며, BMI와 비교하여 LAP 지수는 심혈관계 질환 발병을 예측하는 더 나은 지표라고 보고하였다[1,2]. 또 다른 연구에서 는 아르헨티나의 건강한 성인남성을 대상으로 LAP 지수가 대사 증후군 위험을 예측할 수 있는 신뢰성 있는 진단지표임을 제시 하였다[30].

LAP 지수는 비당뇨병 환자에서 인슐린 저항성을 확인하는

Table 2. The correlation between LAP, ALT and cardiometabolic risk factors

\begin{tabular}{lcc}
\hline \multirow{2}{*}{ Variable } & \multicolumn{2}{c}{ LAP index } \\
\cline { 2 - 3 } & $\begin{array}{c}\text { Correlation } \\
\text { coefficient }\end{array}$ & $p$ \\
\hline ALT (IU/L) & 0.238 & $<0.001$ \\
Waist circumference (cm) & 0.623 & $<0.001$ \\
Systolic BP (mmHg) & 0.201 & $<0.001$ \\
Diastolic BP (mmHg) & 0.201 & $<0.001$ \\
Total cholesterol (mg/dL) & 0.285 & 0.078 \\
HDL-C (mg/dL) & -0.369 & $<0.001$ \\
LDL-C (mg/dL) & 0.120 & $<0.001$ \\
Triglyceride (mg/dL) & 0.885 & $<0.001$ \\
Fasting glucose (mg/dL) & 0.217 & $<0.001$ \\
HbA1c (\%) & 0.207 & $<0.001$ \\
Insulin (uU/mL) & 0.449 & $<0.001$ \\
HOMA-IR & 0.132 & $<0.001$ \\
\hline
\end{tabular}

Calculated by Pearson correlation coefficient.

Abbreviations: LAP, lipid accumulation product; ALT, alanine aminotransferase; BP, blood pressure; $\mathrm{HDL}-\mathrm{C}$, high density lipoprotein cholesterol; LDL-C, low density lipoprotein cholesterol; HbA1c, hemoglobin A1c; HOMA-IR, homeostasis model assessment-insulin resistance.
강력한 지표이며, 간 효소 역시 대사이상을 예측하는 지표로 보 고된다[31,32]. 이에 본 연구에서는 LAP 지수와 심혈관계 대사 질환 위험요인간의 관련성을 확인한 결과 LAP 지수는 심혈관계 대사질환 위험요인과 상관성을 보이며, 특히 인슐린 및 $\mathrm{HDL}-$ 콜레스테롤과상관성이 높게 나타나 선행연구와 유사한 결과를 보였다. 이와 같은 결과는 복부비만을 반영하는 허리둘레가 대 사증후군의 주요 구성요소이며, 허리둘레와 중성지방은 인슐린 저항성 및 심혈관 질환 위험을 예측하는 인자이기 때문이다[1,2].

한편, 복부비만 및 이상지질혈증은 비알콜성 지방간질환 (non-alcoholic fatty liver disease, NAFLD)의 중요한 위험 요 소이다[18-21]. 비알콜성 지방간은 만성 대사성 질환으로 비 만, 이상지질혈증, 대사증후군 및 제 2형 당뇨와 관련이 있다 [33,34]. 간세포 손상의 일반적이며 유용한 지표인 ALT는 비알 콜성 지방간 및 대사증후군 위험요인과 밀접한 관련이 있으며, ALT는 다른 간 효소와 비교하여 간 세포내 지방 축적을 잘 반영 하는 지표라는 사실이 밝혀졌다[14,15,32]. 또한 복부비만 특 히 내장지방 축적은 비알콜성 지방간의 위험요인이며, 이소성 지질 침착을 반영하는 고중성지방혈증은 비알콜성 지방간의 발 병에 기여하는 것으로 알려져 있다[18-21]. 따라서 LAP 지수는 내장지방 축적과 비알콜성 지방간 및 ALT치와 관련이 있을 것 으로 추정된다[22]. 선행연구에 따르면 Bedogni 등[25]은 간질 환자를 대상으로 LAP 지수와 간 지방증간의 관련성을 분석한 결과 간 지방증의 중증도는 LAP 지수에 비례하여 증가한다고 보고하였다. 또한 Ji 등[22]은 간 질환이 없는 정상성인을 대상

Table 4. Odds ratios for elevated ALT levels in different quartiles of LAP

\begin{tabular}{|c|c|c|c|}
\hline \multicolumn{2}{|c|}{ Variable } & $\begin{array}{l}\text { OR }(95 \% \mathrm{CI}) \text { for } \\
\text { elevated ALT levels }\end{array}$ & $p$ \\
\hline \multirow[t]{4}{*}{ LAP index } & \multicolumn{3}{|c|}{ Quartile 1 (reference) } \\
\hline & Quartile 2 & $2.233(1.773 \sim 2.814)$ & $<0.001$ \\
\hline & Quartile 3 & $4.362(3.513 \sim 5.415)$ & $<0.001$ \\
\hline & Quartile 4 & $10.844(8.790 \sim 13.378)$ & $<0.001$ \\
\hline
\end{tabular}

Calculated by binominal logistic regression analysis.

Binominal logistic regression was adjusted for age.

Abbreviations: OR, odds ratios; LAP, lipid accumulation product.

Table 3. Multivariate linear regression analysis the impact of variables on ALT

\begin{tabular}{|c|c|c|c|c|c|c|}
\hline Independent variable & Dependent variable & $B$ & SE & $\beta$ & $p$ & $95 \% \mathrm{Cl}$ for $\beta$ \\
\hline LAP index & ALT (IU/L) & $\begin{array}{r}0.234 \\
F=452.46^{\star \star}\end{array}$ & $\begin{array}{l}0.008 \\
\text {, Adj } R^{2}\end{array}$ & 0.240 & $<0.001$ & $0.218 \sim 0.250$ \\
\hline
\end{tabular}

Calculated by multivariable linear regression analysis adjusted for age.

${ }^{* *} p<0.001$.

Abbreviations: ALT, alanine aminotransferase; LAP, lipid accumulation product. 
으로 LAP 지수와 ALT간에 관련이 있음을 입증하였으며, LAP 지수를 4 분위수로 나누어 그 위험도를 확인한 결과 1 사분위수 보다 4사분위수에서 ALT 상승이 나타날 확률이 3.61배 높다고 보고하였다.

본 연구결과 LAP 분위수가 증가할수록 ALT는 증가하였으며, LAP 지수는 ALT치에 영향을 미치는 요인으로 나타났다. 또한 $\mathrm{LAP}$ 사분위수에 따른 ALT의 이상치 발생가능성은 1 사분위수 와 비교해 2 사분위수에서 2.2 배 증가하며, 3 사분위수에서는 4.4 배, 4 사분위수에서는 10.8 배 증가하는 것으로 나타났다. 이 는 LAP 지수가 높을수록 ALT가 상승할 위험이 높게 나타나 성 인남성에서 LAP 지수가 ALT 상승을 예측하는 좋은 지표로 간주 된다[22].

복부비만은 간염, 간 섬유증 및 비알콜성 지방간질환에 중요 한 역할을 하는데, 과도한 내장지방은 간 세포에 유리지방산 축 적과 NF-kB (Nuclear factor kappa B)활성화에 따른 IL-6 (Interleukin-6), TNF- $\alpha$ (tumor necrosis factor- $\alpha$ ) 같은 전 염증성 사이토카인(proinflammatory cytokines)의 과도한 분 비로 인슐린 저항성과 비알콜성 지방간의 악화를 초래한다고 알려져 있다[4,35]. 허리둘레는 복부비만을 진단하는 지표이지 만 피하지방과 내장지방의 축적을 구별하기는 어렵다[5]. 그러 나 중성지방은 복부 피하지방 조직을 통제한 후에도 건강한 남 성에서 내장지방과 유의한 상관관계를 나타내며[8], "hypertriglyceridemic waist”라는 허리둘레와 함께 중성지방을 병합 한 지표를 적용하면 내장지방을 식별 할 수 있다고 알려진다[9]. 따라서 LAP 지수는 내장지방 축적을 더 잘 인식 할 수 있으며 [8], 허리둘레 및 중성지방의 단일 지표를 적용한 경우보다 비알 콜성 지방간 또는 ALT 수준과 더 관련이 있을 수 있다[22].

이 연구의 잠재적 제한점으로는 건강한 성인남성을 대상으 로 하여 혈청 ALT치가 정상 또는 경미한 상승을 보이고 있어 $\mathrm{LAP}$ 지수와 ALT간의 상관관계를 확증하기 위해서는 다양한 연 령대와 대상자를 통한 추가적인 연구가 필요하다. 이 연구는 횡 단면 연구이기 때문에 LAP 지수와 ALT간의 관련성만을 확인할 수 있었으며, 인과관계를 알 수는 없었다. LAP 지수의 허리둘레 와 중성지방은 식이에 영향을 받는 요인이지만 이와 관련된 조 사가 배제되었다. 또한 간질환의 병력이 없는 건강한 성인남성 을 대상자로 하였으나, ALT 농도에 영향을 미치는 알코올 섭취 량은 고려하지 못했다. 그러나간 손상과 관련이 있는 ALT에 영 향을 미치는 위험 요소를 확인하는 것은 비알콜성 지방간질환 을 예방하는데 중요하며, LAP 지수는 ALT 상승을 예측하는 지 표로서 이를 조절하는 것이 비알콜성 지방간질환의 예방을 위 해 고려될 수 있겠다.
결론적으로 허리둘레와 중성지방으로 구성된 LAP 지수는 ALT와 관련이 있으며, ALT에 영향을 미치는 요인이었다. 또한 $\mathrm{LAP}$ 지수는 심혈관계 대사질환 위험요인과 관련이 있으며, $\mathrm{LAP}$ 지수가 높을수록 ALT의 이상치 발생가능성이 높은 것으로 나타났다. 그러므로 한국의 건강한 성인남성에서 ALT 상승을 예측하는데 위험요인으로 허리둘레와 중성지방을 조합한 LAP 지수의 적용이 가능하겠다.

\section{요 약}

$\mathrm{LAP}$ 지수는 공복시 중성지방 농도와 허리둘레의 조합으로 과도한 지방축적을 평가하는 지표이다. 이 연구는 LAP 지수와 ALT간의 관련성과 LAP 지수가 ALT에 미치는 영향에 대해 알아 보고자 간질환의 병력이 없는 건강한 성인남성을 대상으로 횡 단면 연구를 실시하였다. 2015년 1월부터 2017년 6월까지 경 기지역 종합병원에서 건강검진을 시행한 20세 이상 70 세 이하 의 성인 남성 13,854 명을 연구 대상자로 하였다. LAP 지수는 남 성의 경우 [허리둘레 $(\mathrm{cm})-65] \times[$ 중성지방 $(\mathrm{mmol} / \mathrm{L})]$ 으로 산출 하였으며, 혈청 ALT 농도의 이상치는 남성 $40 \mathrm{IU} / \mathrm{L}$ 이상인 경우 를 기준으로 설정하였다. 모든 대상자들은 인체측정학적 지표와 생리학적 검사를 실시하였다. LAP 분위수가 증가할수록 ALT는 통계적으로 유의한 증가를 보였다 $(p<0.001)$. LAP 지수는 ALT 와 상관관계를 보였으며 $(r=0.238, p<0.001)$, 특히 인슐린 $(r=0.449, p<0.001)$ 및 $\mathrm{HDL}-$ 콜레스테롤 $(r=-0.369, p<0.001)$ 과상관성이 높게 나타났다. 또한 LAP 지수는 ALT에 영향을 미 치는 요인이었으며 $(p<0.001), \mathrm{LAP}$ 지수가 높을수록 ALT가 상 승할 위험이 높게 나타났다 $(p<0.001)$. 결론적으로 LAP 지수 는 한국 성인남성에서 ALT 상승을 예측하는 지표로 나타났다.

\section{Acknowledgements: None}

Funding: None

Conflict of interest: None

\section{REFERENCES}

1. Kahn HS. The "lipid accumulation product" performs better than the body mass index for recognizing cardiovascular risk: a population-based comparison. BMC Cardiovasc Disord. 2005; 5:26.

2. Kahn HS. The lipid accumulation product is better than BMI for identifying diabetes: a population-based comparison. Diabetes Care. 2006;29(1):151-153.

3. Hamdy O, Porramatikul S, Al-Ozairi E. Metabolic obesity: the 
paradox between visceral and subcutaneous fat. Curr Diabetes Rev. 2006;2(4):367-373.

4. Freedland ES. Role of a critical visceral adipose tissue threshold (CVATT) in metabolic syndrome: implications for controlling dietary carbohydrates: a review. Nutr Metab (Lond). 2004;1(1):12.

5. Vieira BA, Sauer P, Marcadenti A, Piovesan CH. Association between LAP Index (Lipid Accumulation Product) and metabolic profile in hospitalized patients. Nutr Hosp. 2015;31(○):2771-2774.

6. Carneiro Roriz AK, Santana Passos LC, Cunha de Oliveira C, Eickemberg M, de Almeida Moreira P, Ramos Sampaio L. Discriminatory power of indicators predictors of visceral adiposity evaluated by computed tomography in adults and elderly individuals. Nutr Hosp. 2014;29(6):1401-1407.

7. Roriz AK, Passos LC, de Oliveira CC, Eickemberg M, Moreira Pde A, Sampaio LR. Evaluation of the accuracy of anthropometric clinical indicators of visceral fat in adults and elderly. PLoS One. 2014;9(7):e103499.

8. Nguyen-Duy TB, Nichaman MZ, Church TS, Blair SN, Ross R. Visceral fat and liver fat are independent predictors of metabolic risk factors in men. Am J Physiol Endocrinol Metab. 2003;284(6):E1065-1071.

9. Sam S, Haffner S, Davidson MH, D'Agostino RB Sr, Feinstein S, Kondos G, et al. Hypertriglyceridemic waist phenotype predicts increased visceral fat in subjects with type 2 diabetes. Diabetes Care. 2009;32(10):1916-1920.

10. Zainuddin LR, Isa N, Muda WM, Mohamed HJ. The prevalence of metabolic syndrome according to various definitions and hypertriglyceridemic-waist in malaysian adults. Int J Prev Med. 2011;2(4):229-237.

11. Amini M, Esmaillzadeh A, Sadeghi M, Mehvarifar N, Amini M, Zare M. The association of hypertriglyceridemic waist phenotype with type 2 diabetes mellitus among individuals with first relative history of diabetes. J Res Med Sci. 2011;16(2):156-164.

12. Blackburn P, Lemieux I, Lamarche B, Bergeron J, Perron P, Tremblay G, et al. Hypertriglyceridemic waist: a simple clinical phenotype associated with coronary artery disease in women. Metabolism. 2012;61(1):56-64.

13. Ioachimescu AG, Brennan DM, Hoar BM, Hoogwerf BJ. The lipid accumulation product and all-cause mortality in patients at high cardiovascular risk: a PreCIS database study. Obesity (Silver Spring). 2010;18(9):1836-1844.

14. Clark JM, Brancati FL, Diehl AM. The prevalence and etiology of elevated aminotransferase levels in the United States. Am J Gastroenterol. 2003;98(5):960-967.

15. Kim WR, Flamm SL, Di Bisceglie AM, Bodenheimer HC; Public Policy Committee of the American Association for the Study of Liver Disease. Serum activity of alanine aminotransferase (ALT) as an indicator of health and disease. Hepatology. 2008;47(4): 1363-1370.

16. Vernon G, Baranova A, Younossi ZM. Systematic review: the epidemiology and natural history of non-alcoholic fatty liver disease and non-alcoholic steatohepatitis in adults. Aliment Pharmacol Ther. 2011;34(3):274-285.

17. Schindhelm RK, Diamant M, Dekker JM, Tushuizen ME, Teerlink T, Heine RJ. Alanine aminotransferase as a marker of non-alcoholic fatty liver disease in relation to type 2 diabetes mellitus and cardiovascular disease. Diabetes Metab Res Rev. 2006;
22(6):437-443.

18. Després JP, Cartier A, Côté M, Arsenault BJ. The concept of cardiometabolic risk: bridging the fields of diabetology and cardiology. Ann Med. 2008;40(7):514-523.

19. Kallwitz ER, Kumar M, Aggarwal R, Berger R, Layden-Almer J, Gupta N, et al. Ethnicity and nonalcoholic fatty liver disease in an obesity clinic: the impact of triglycerides. Dig Dis Sci. 2008;53(5):1358-1363.

20. Eguchi Y, Eguchi T, Mizuta T, Ide Y, Yasutake T, Iwakiri R, et al. Visceral fat accumulation and insulin resistance are important factors in nonalcoholic fatty liver disease. J Gastroenterol. 2006;41(5):462-469.

21. van der Poorten D, Milner KL, Hui J, Hodge A, Trenell MI, Kench JG, et al. Visceral fat: a key mediator of steatohepatitis in metabolic liver disease. Hepatology. 2008;48(2):449-457.

22. Ji BL, Li R, Zhang SH, Gong LL, Wang ZH, Ren W, et al. The lipid accumulation product is highly related to serum alanine aminotransferase level in male adults. Nutr Res. 2012;32(8):581-587.

23. Dai H, Wang W, Chen R, Chen Z, Lu Y, Yuan H. Lipid accumulation product is a powerful tool to predict non-alcoholic fatty liver disease in Chinese adults. Nutr Metab (Lond). 2017;14:49.

24. Deurenberg-Yap M, Chew SK, Deurenberg P. Elevated body fat percentage and cardiovascular risks at low body mass index levels among Singaporean Chinese, Malays and Indians. Obes Rev. 2002;3(3):209-215.

25. Bedogni G, Kahn HS, Bellentani S, Tiribelli C. A simple index of lipid overaccumulation is a good marker of liver steatosis. BMC Gastroenterol. 2010;10:98.

26. Xiang S, Hua F, Chen L, Tang Y, Jiang X, Liu Z. Lipid accumulation product is related to metabolic syndrome in women with polycystic ovary syndrome. Exp Clin Endocrinol Diabetes. 2013;121(2):115-118.

27. Mirmiran P, Bahadoran Z, Azizi F. Lipid accumulation product is associated with insulin resistance, lipid peroxidation, and systemic inflammation in type 2 diabetic patients. Endocrinol Metab (Seoul). 2014;29(4):443-449.

28. Moon K, Sung SH, Chang YK, Park IK, Paek YM, Kim SG, et al. The association between Apolipoprotein E genotype and lipid profiles in healthy woman workers. J Prev Med Public Health. 2010;43(3):213-221.

29. Dobbelsteyn CJ, Joffres MR, MacLean DR, Flowerdew G. A comparative evaluation of waist circumference, waist-to-hip ratio and body mass index as indicators of cardiovascular risk factors. The Canadian Heart Health Surveys. Int J Obes Relat Metab Disord. 2001;25(5):652-661.

30. Tellechea ML, Aranguren F, Martínez-Larrad MT, Serrano-Ríos M, Taverna MJ, Frechtel GD. Ability of lipid accumulation product to identify metabolic syndrome in healthy men from Buenos Aires. Diabetes Care. 2009;32(7):e85.

31. Xia C, Li R, Zhang S, Gong L, Ren W, Wang Z, et al. Lipid accumulation product is a powerful index for recognizing insulin resistance in non-diabetic individuals. Eur J Clin Nutr. 2012; 66(9):1035-1038.

32. Shin KA. The clinical implications of hepatic enzymes in metabolically healthy obese men. Korean J Clin Lab Sci. 2017; 49(3):248-255.

33. Lazo M, Clark JM. The epidemiology of nonalcoholic fatty liver 
disease: a global perspective. Semin Liver Dis. 2008;28(4):339350.

34. Fan JG, Farrell GC. Epidemiology of non-alcoholic fatty liver disease in China. J Hepatol. 2009;50(1):204-210.
35. Cai D, Yuan M, Frantz DF, Melendez PA, Hansen L, Lee J, et al. Local and systemic insulin resistance resulting from hepatic activation of IKK-beta and NF-kappaB. Nat Med. 2005;11(2): 183-190. 